\title{
PASAR DAN PEMASARAN
}

Makalah Ini Disusun untuk Memenuhi Tugas pada Mata Kuliah Kewirausahaan

Dosen Pengampuh : Dra. Hj. Nuraeni Gani, MM.

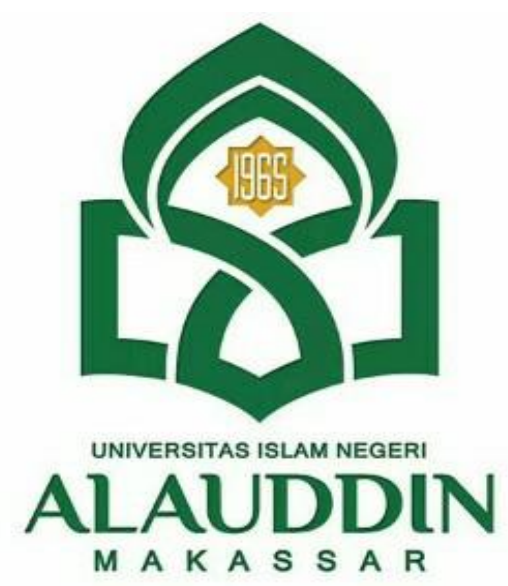

\author{
RAHMI \\ 90500120121 \\ rahmi@gmail.com
}

PRODI PERBANKAN SYARIAH

FAKULTAS EKONOMI DAN BISNIS ISLAM UNIVERSITAS ISLAM NEGERI ALAUDDIN MAKASSAR TAHUN 2021 


\begin{abstract}
ABSTRAK
Pasar adalah salah satu tempat dimana adanya traksaksi antara penjual dan pembeli. Dalam pasar terdapat beberapa kelompok yaitu, pasar konsumen, pasar industrial, pasar reseller dan pasar pemerintah. Sedangkan pemasaran adalah suatu usaha yang didalamnya terdapat tujuan untuk memenuhi kebutuhan para konsumen dengan menciptakan produkproduk yang dibutuhkannya. Dalam pemasaran terdapat permintaan dan penawaran yang akan mempengaruhi jalannya usaha dalam pemasaran tersebut. Permintaan didukung dengan adanaya keinginan dari konsumen untuk membeli produk yang kita pasarkan. Sedangkan penawaran adalah penawaran yang dilakukan pembeli atau konsumen terhadap barang atau jasa yang dimiliki oleh penjual.
\end{abstract}

Kata kunci: Pasar, Pemasaran, Permintaan dan Penawaran. 


\section{KATA PENGANTAR}

Puji syukur kehadirat Allah SWT yang telah memberikan rahmat dan hidayahNya sehingga saya dapat menyelesaikan tugas makalah yang berjudul "Pasar Dan Pemasaran" ini dengan tepat waktu. Adapun tujuan dari makalah ini adalah untuk memenuhi tugas pada mata kuliah Kewirausahaan. Selain itu, makalah ini bertujuan untuk menambah wawasan tentang Pasar dan Pemasaran bagi para pembaca dan juga penulis.

Saya mengucapkan terima kasih kepada Ibu Dra. Hj. Nuraeni Gani, MM, selaku dosen yang telah memberikan tugas ini sehingga dapat menambah pengetahuan dan wawasan sesuai bidang yang saya tekuni.

Makalah yang saya tulis ini masih jauh dari kata sempurna. Oleh karena itu, kritik dan saran yang membangun akan saya nantikan demi kesempurnaan makalah ini.

Toraja, 26 Nov 2021

Rahmi 


\section{DAFTAR ISI}

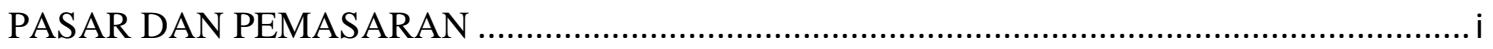

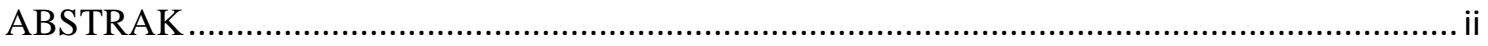

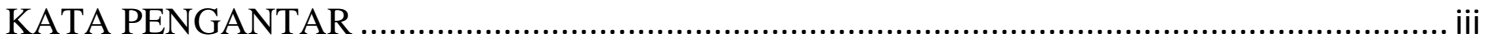

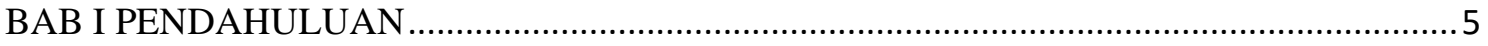

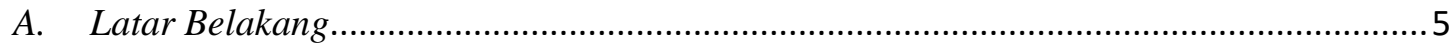

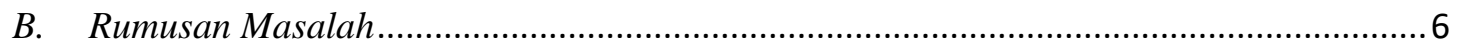

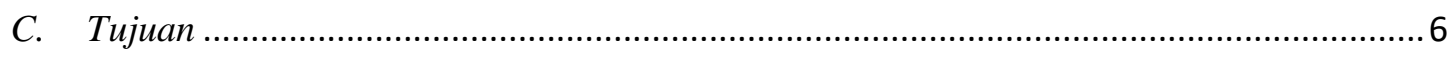

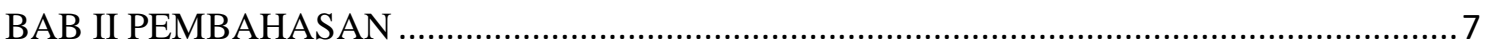

A. Peran Pasar dan Pemasaran ....................................................................................

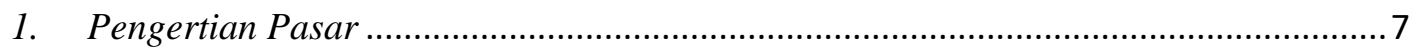

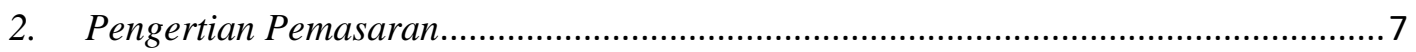

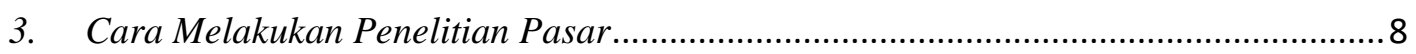

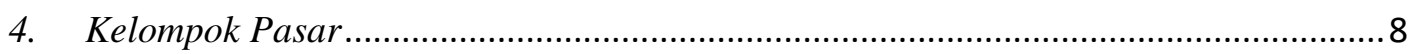

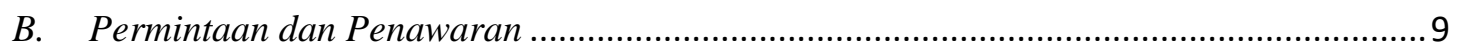

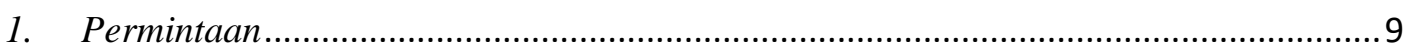

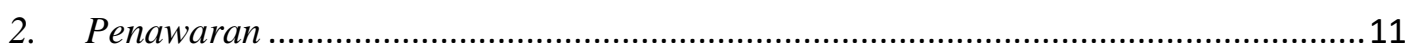

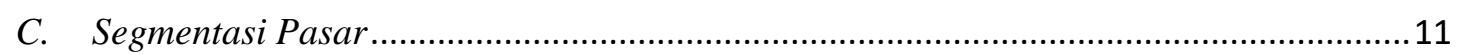

1. Variabel Utama Dalam Segmentasi Pasar Konsumen .............................................11

2. Variabel Utama Dalam Segmentasi Pasar Industrial ..............................................12

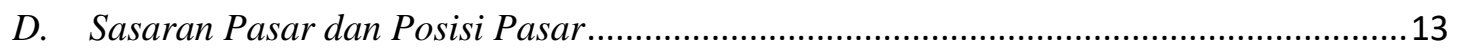

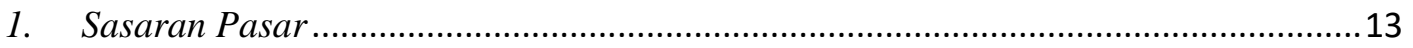

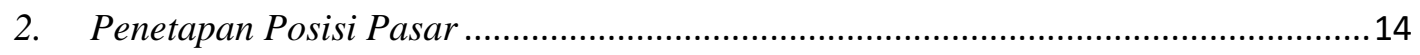

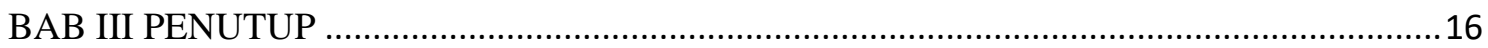

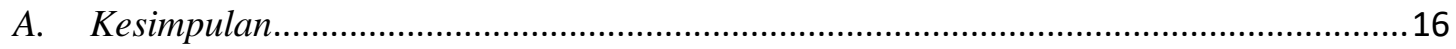

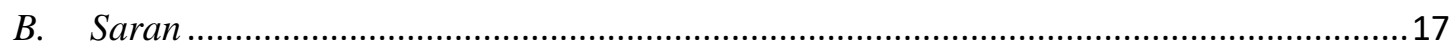

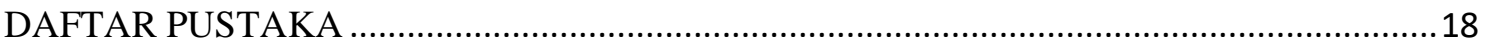




\section{BAB I}

\section{PENDAHULUAN}

\section{A. Latar Belakang}

Dalam ilmu ekonomi, tidak akan terlepas dari kata "pasar” juga “pemasaran”. Pasar merupakan salah satu faktor yang mendukung jalannya ekonomi masyarakat. Pasar merupakan suatu kegiatan jual beli antara penjual dan pembeli pada suatu tempat tertentu. Dalam melakukan jual beli ada dua cara baik itu secara langsung ataupun tidak langsung (online). Pasar merupakan suatu kegiatan ekonomi yang sangat penting dalam kehidupan sehari-hari khususnya dalam bidang ekonomi. Masyarakat pun tidak akan bisa terpenuhi kebutuhannya tanpa adanya pasar.

Dalam suatu bisnis akan ada usaha yang dilakukan oleh pengelolahnya untuk memasarkan produknya. Rencana pemasaran yang baik merupakan awal yang baik pula untuk jalannya usaha kita di masa yang akan datang. Pemasaran merupakan suatu kegiatan atau upaya yang dilakukan untuk memenuhi keinginan para konsumen. Dalam tahap pemasaran akan ada penawaran ataupun permintaan dari konsumen yang pastinya akan berpengaruh pada usaha kita. Permintaan merupakan satu kegiatan perilaku konsumen dalam kegiatan ekonomi terhadap barang atau jasa yang diminta pada tingkat harga tertentu. Sedangkan penawaran merupakan tindakan yang dilakukan konsumen untuk menawar harga pada barang atau jasa yang telah ditetapkan sebelumnya. Ada beberapa faktor yang dapat mempengaruhi permintaan dan penawaran, seperti : harga barang, harga barang pengganti (pelengkap), jumlah penduduk, selera konsumen, jumlah pendapatan konsumen, teknologi yang digunakan, harga produksi, dan lain sebagainya. 


\section{B. Rumusan Masalah}

1. Bagaimana peran dan pentingnya pasar dan pemasaran?

2. Apa pengertian permintaan dan penawaran dan faktor yang mempengaruhinya?

3. Bagaimana segmentasi pasar?

4. Bagaimana sasaran pasar dan posisi pasar ?

\section{Tujuan}

1. Untuk mengetahui dan memahami peran dan pentingnya pasar dan pemasaran ?

2. Untuk mengetahui dan memahami pengertian permintaan dan penawaran dan faktor yang mempengaruhinya?

3. Untuk mengetahui dan memahami bagaimana segmentasi pasar ?

4. Untuk mengetahui dan memahami bagaimana sasaran pasar dan posisi pasar ? 


\section{BAB II}

\section{PEMBAHASAN}

\section{A. Peran Pasar dan Pemasaran.}

\section{Pengertian Pasar}

Pasar merupakan transaksi jual beli yang dilakukan oleh penjual dan pembeli pada saat tertentu di tempat tertentu. Di era globalisasi saat ini, gaya hidup dan kebutuhan masyarakat akan semakin meningkat. Sehingga masyarakat membutuhkan suatu tempat yang didalamnya menyediakan berbagai kebutuhan-kebutuhan hidup yang mereka inginkan. Dari sanalah bermula dibutuhkannya pasar dalam kehidupan masyarakat. Adapun syarat-syarat terbentuknya pasar adala sebagai berikut:

a. Adanya penjual dan pembeli

b. Adanya barang atau jasa untuk diperjualbelikan

c. Terjadinya kesepakatan antara penjual dan pembeli

Menurut Staton, pasar adalah orang-orang yang mempunyai keinginan untuk puas, uang untuk berbelanja, dan kemauan untuk membelanjakannya. Pasar merupakan jantung ekonomi bangsa, karena kondisi pasar sangat mempengaruhi maju mundurnya perekonomian bangsa.

\section{Pengertian Pemasaran}

Pemasaran merupakan upaya memasarkan sebuah produk, baik itu barang atau jasa, dengan menggunakan pola rencana dan taktik tertentu sehingga jumlah penjualan menjadi lebih tinggi dan mempunyai banyak keuntungan.

Menurut Tjiptono (2002, 6), Pemasaran (strategi pemasaran) adalah alat fundamental yang direncanakan untuk mencapai perusahaan dengan mengembangkan 
keunggulan bersaing yang berkesinambungan melalui pasar yang dimasuki program pemasaran yang digunakan untuk melayani pasar sasaran tersebut.

Pemasaran merupakan suatu aktivitas untuk memenuhi kebutuhan dan keinginan yang ada melalui penciptaan proses pertukaran antara penjual dan pembeli yang saling memberikan keuntungan. Tahap- tahap dalam praktek pemasaran yaitu seperti permasaran swadaya, pemasaran terformulasi, dan pemasaran total.

\section{Cara Melakukan Penelitian Pasar}

Penelitian merupakan upaya atau kegiatan yang dilakukan untuk mengamati atau melakukan observasi terhadap suatu tempat dengan tujuan tertentu. Sebelum masuk ke lingkungan pasar, pada tahap awal seharusnya melakukan penelitian terhadap pasar yang akan kita tempati. Cara tersebut merupakan konsep awal yang baik yang akan

mempermudah jalannya usaha kita dalam pasar nantinya. Berikut beberapa cara dalam penelitian pasar :

a. Observasi adalah pengamatan secara langsung lokasi penelitian. Hasilnya sesuai dengan fenomena yang terjadi di lapangan.

b. Melakukan wawancara kepada informan atau yang bersangkutan dalam pasar.

c. Menyebarkan kuisioner ke berbagai calon konsumen agar dapat mengetahui kebutuhan dan keinginan mereka untuk kita pasarkan.

d. Melakukan pemasangan iklan untuk menawarkan produk walaupun belum ada, untuk melihat respon konsumen.

\section{Kelompok Pasar}

Kelompok dalam pasar terdiri dari empat, yaitu :

a. Pasar Konsumen adalah sekelompok pembeli yang membeli barang untuk dikonsumsikan, bukannya dijual atau diproduksi kembali. Yang berperan dalam pasar 
konsumen ini adalah pembeli rumah tangga atau pembeli-pembeli individual. Barang yang dibeli adalah barang konsumsi.

b. Pasar industri adalah pasar yang terdiri atas individu-individu dan lembaga atau organisasi yang membeli barang untuk dipakai lagi, baik secara langsung maupun secara tidak langsung, yang kemudian diproduksi dan dijual kembali. Barang yang dibeli adalah barang industri.

c. Pasar penjual adalah pasar yang terdiri dari individu-individu dan organisasi atau lembaga yang membeli barang-barang untuk dijual atau disewakan kepada konsumen untuk mendapatkan keuntungan (laba).

d. Pasar pemerintah adalah pasar yang didalamnya terdapat campur tangan pemerintah, seperti diktorat, departemen, kantor dinas, dan instansi lainnya

\section{B. Permintaan dan Penawaran}

\section{Permintaan}

Permintaan adalah suatu keinginan dari konsumen baik itu barang atau jasa untuk dibeli pada waktu tertentu. Keinginan tersebut didukung oleh daya beli dan akses untuk pembeli. Permintaan akan terjadi jika didukung oleh kemampuan keuangan yang dimiliki seorang konsumen untuk membeli barang atau jasa. Adapun faktor yang mempengaruhi permintaan adalah sebagai berikut :

a. Harga pengganti (substitusi)

Harga barang dan jasa pengganti juga ikut mempengaruhi jumlah pada barang atau jasa yang diminta konsumen. Jika konsumen memilih barang substitusi maka harga barang tersebut murah. Akan tetapi, jika konsumen memilih beralih ke barang lain maka dipastikan harga barang substitusi tersebut naik.

b. Harga barang pelengkap (komplementer) 
Harga bahan pelengkap seperti contoh tabung gas, yang jika tabung gas tersebut naik maka akan mempengaruhi permintaan konsumen (akan menurun) begitupun sebaliknnya. Harga barang pelengkap ini sangat berpengaruh pada permintaan barang dan jasa.

c. Selera konsumen

Selera konsumen juga sangat berpengaruh dalam permintaan barang dan jasa, jika permintaan terhadarp barang atau jasa mengalami peningkatan, berarti selera konsumen juga meningkat.

d. Jumlah pendapatan

Pada jumlah pendapatan, juga merupakan salah satu yang dapat mempengaruhi permintaan. Jika permintaan pada suatu barang atau jasa meningkat, maka jumlah pendapatan konsumen pasti naik. Tapi jika permintaan menurun, maka bisa jadi jumlah pendapatan konsumen menurun.

e. Intensitas kebutuhan konsumen

Jika permintaan pada barang dan jasa meningkat, maka intensitas kebutuhan konsumen juga akan mendesak untu dipenuhi kebutuhannya. Tapi jika permintaan menurun, maka tingkat intensitas kebutuhan konsumen berada pada tingkat stabil (terpenuhi kebutuhannya).

f. Perkiraan harga di masa depan

Pada salah satu faktor yang mempengaruhi permintaan ini, konsumen akan memperkirakan harga di masa depan. Sehingga konsumen akan berebutan memborong barang yang mereka butuhkan agar saat peningkatan harga di masa depan terjadi, konsumen masih mepunyai stok barang yang mereka butuhkan.

g. Jumlah penduduk 
Jika jumlah penduduk pada suatu tempat meningkat, maka akan mempengaruhi bertambahnya permintaan paa suatu barang dan jasa, begitupun sebaliknya.

\section{Penawaran}

Penawaran adalah upaya yang dilakukan para konsumen untuk menawar harga yang ditetapkan pada barang dan jasa agar harga tersebut bisa menurun sesuai yang di inginkannya. Adapun faktor yang mempengaruhi penawaran adalah :
a. Harga barang itu sendiri
b. Harga barang lain yang memiliki hubungan (barang pelengkap)
c. Teknologi yang digunakan
d. Harga input (biaya produksi)
e. Tujuan perusahaan
f. Faktor khusus (akses)

\section{Segmentasi Pasar}

Segmentasi pasar adalah kegiatan membagi-bagi pasar yang bersifat heterogen dari suaru produk kedalam satuan-satuan pasar (segmen pasar) yang bersifat homogen. Dalam pengertian lain, segmentasi pasar adalah kegiatan membagi-bagi pasar menjadi beberapa kelompok pembeli berbeda yang mungkin memerlukan barang atau jasa yang berbeda pula. Segmentasi pasar merupakan langkah awal dari seorang pengusaha untuk memasuki pasar (tahap perencanaan).

\section{Variabel Utama Dalam Segmentasi Pasar Konsumen}

Dalam segmentasi pasar konsumen, diperlukan beberapa variabel utama untuk mendukung segmentasi pasar, sebagai berikut: 
a. Segmentasi atas dasar geografis, dilakukan dengan cara membagi pasar kedalam unit-unit geografis seperti negara, provinsi, kabupaten, kota, desa, dan lain sebagainya.

b. Segmentasi atas dasar demografs, dilakukan dengan cara memisahkan pasar kedalam kelompok-kelompok yang didasarkan pada variabel-variabel demografis (umur, jenis kelamin, besarnya keluarga, pendapatan, pendidikan, agama, pekerjaan, dan lain sebagainya,

c. Segmentasi atas dasar psikografis, dilakukan dengan cara membagi-bagi konsumen kedalam beberapa kelompok yang berlainan menurut kelas sosial, gaya hidup, berbagai ciri kepribadian, motif pembelian, dan lain sebagainya.

d. Segmentasi atas dasar perilaku, dilakukan dengan cara membagi-bagi konsumen kedalam beberapa kelompok dilihat dari pengetahuan, sikap, kegunaan, dan tanggapan terhadap suatu produk.

\section{Variabel Utama Dalam Segmentasi Pasar Industrial}

Berikut beberapa variabel utama dalam segmentasi pasar industrial :

a. Segmentasi atas dasar demograsi, yang dilakukan dalam segmentasi ini adalah dengan memperhatikan jenis industri, besar perusahaan, dan lokasi perusahaan.

b. Segmentasi atas dasar karakteristik pengoperasian, yang dilakukan dalam segmentasi ini adalah bagaimana teknologi yang difokuskan, status pengguna baik itu berat, sedang, atau ringan, dan kemampuan pelanggan dalam membeli produk barang atau jasa yang perusahaan sediakan. 
c. Segmentasi atas dasar pendekatan pembeli, pada segmentasi ini terdiri dari organisasi yang berfungsi sebagai pembeli, sifat hubungan yang ada, struktur kekuatan, kebijakan pembelian umum, serta kriteria.

d. Segmentasi atas dasar personal industri, yang dilakukan adalah dengan membagi-bagi kelompok konsumen dengan melihat kesamaan pembeli, sikap terhadap resiko, dan kriteria.

e. Segmentasi atas dasar faktor situasional, yang terdiri dari urgensi, pengguna khusus, dan besarnya pesanan pelanggan.

\section{Sasaran Pasar dan Posisi Pasar}

\section{Sasaran Pasar}

Sasaran pasar dapat dilakukan setelah segmentasi pasar, dengan cara mengembangkan ukuran-ukuran dan daya tarik segmen pasar. Dalam memilih sasaran pasar agar optimal ada beberapa kriteria yang perlu diperhatikan :

a. Responsif.

Langkah ini harus dimulai dengan studi segementasi yang jelas karena tanpa sasaran pasar yang jelas maka perusahaan akan menanggung resiko yang terlalu besar.

b. Potensi Penjualan

Potensi penjualan harus jelas dan luas. Semakin besar sasaran pasar, maka semakin besar nilai yang didapatkan. Dimana besarnya bukan hanya ditentukan dengan jumlah populasi tapi juga daya beli dan keinginan pasar untuk memeliki produk tersebut. c. Pertumbuhan yang memadai

Pasar akan tumbuh secara perlahan-lahan sehingga pada akhirnya mencapai titik yang di inginkan perusahaan.

d. Jangkauan media 
Jangkauan media sangat diperlukan dalam pemasaran untuk menentukan sasaran pasar. Perusahaan harus mampu mempromosikan atau memperkenalkan produknya menggunakan media untuk menarik perhatian kosumen.

\section{Penetapan Posisi Pasar}

penetapan posisi pasar adalah strategi pemasaran yang berfokus pada penciptaan citra atau persepsi unik dari suatu merek, produk, atau layanan di benak pelanggan. Posisi pasar di upayakan berada pada lokasi yang kompetitif untuk produk atau suatu pasar. Berikut cara membuat startegi penentuan posisi pasar agar bisa berhasil, sebagai berikut

a. Mengidentifikasi kekuatan perusahaan melalui analisis pesaing.

b. Menganalisis posisi pasar saat ini.

c. Menganalisis penetuan posisi pesaing terperinci.

d. Membuat strategi penentuan posisi pasar.

Ada beberapa keuntungan yang didapat jika penentuan posisi pasar atau market positioning tepat, yaitu:

a. Peningkatan pendapatan. Ketika sebuah merek berhasil menciptakan posisi pasar yang unik, maka pendapatannya meningkat karena adanya peningkatan volume penjualan.

b. Membangun keuntungan yang kompetitif. Dalam penentuan posisi pasar juga akan membantu merek menciptakan keunggulan yang kompetitif.

c. Mudah mempromosikan produk baru. Dengan memposisikan perusahaan di pasar dapat mempermudah perusahaan untuk menambah atau meluncurkan produk baru dalam pasar. 
d. Buat identitas merek. Hanya dengan penentuan posisi pemasaran yang tepat sehingga dapat mengembakan citra atau persepsi di benak pelanggan.

e. Posisi pemasaran menyederhanakan keputusan pembeli untuk pelanggan. 


\section{BAB III}

\section{PENUTUP}

\section{A. Kesimpulan}

Pasar merupakan jantung ekonomi suatu bangsa yang akan mempengaruhi maju mundurnya perekonomian. Dalam pasar, sangat dibutuhkan untuk menyusun strategi pemasaran yang baik. Pemasaran adalah upaya atau kegiatan yang dilakukan oleh pemasaran untuk memproduksi barang atau jasa nyang bertujuan untuk memenuhi keinginan konsumen. Terdapat empat kelompok dalam pasar, yaitu: pasar konsumen, pasar industrial, pasar penjual (reseller), dan pasar pemerintah.

Permintaan adalah upaya yang dilakukan konsumen kepada perusahaan agar keinginan dan kebutuhan hidupnya bisa terpenuhi dengan didukung oleh daya beli konsumen. Ada beberapa faktor yang mempengaruhi permintaan konsumen yaitu :
a. Harga pengganti (substitusi)
b. Harga barang pelengkap (komplementer)
c. Selera konsumen
d. Jumlah pendapatan
e. Intensitas kebutuhan konsumen
f. Perkiraan harga di masa depan
g. Jumlah penduduk

Penawaran adalah upaya yang dilakukan konsumen dengan tujuan agar barang atau jasa pada perusahaan bisa diturunkan harganya sesuai dengan keinginan konsumen. Berikut beberapa faktor yang mempengaruhi penawaran :

a. Harga barang itu sendiri 
b. Harga barang lain yang memiliki hubungan (barang pelengkap)

c. Teknologi yang digunakan

d. Harga input (biaya produksi)

e. Tujuan perusahaan

f. Faktor khusus (akses)

Setelah melakukan segmentasi dalam pasar, selanjutnya perusahaan akan melakukan sasaran pasar yang bertujuan untuk mengembangkan ukuran-ukuran dan daya tarik segmen pasar. Kemudian perusahaan melakukan penentuan posisi pasar yang kompetitif dan lokasi yang strategis agar konsumen terus meningkat.

\section{B. Saran}

Dengan membaca makalah ini diharapkan kita mampu memahami lebih jauh tentang Pasar dan Pemasaran, walaupun penulis menyadari bahwa dalam penulisan makalah ini masih terdapat banyak kekurangan. Untuk itu, penulis menyarankan agar mencari referensi-referensi bacaan lebih banyak lagi selain dari makalah ini. 


\section{DAFTAR PUSTAKA}

Hariansah, N. (2021). Segmentasi Pasar Dalam Komunikasi Pemasaran Islam. Jurnal Al-Hikmah, 19 (2), 127-138.

Jordan, A. D. (2020). Mekanisme Hubungan Permintaan Dalam Mempengaruhi Pasar. Jurnal Ekonomi Bisnis dan Kewirausahaan , 4, 1-18.

Kasdi, A. (2016). Permintaan dan Penawaran dalam Mempengaruhi Pasar. Jurnal Bisnis dan Manajemen Islam , 4 (2), 18-34.

Mahesa, Y. (2021, Mei 17). Apa Itu Posisi Pasar (Market Positioning) : Definisi, Jenis, Keuntungan, Cara Kerja. Retrieved Nov 27, 2021, from https://belajarekonomi.com/posisi-pasar/.

Muawanah. (2017). Permintaan dan Penawaran dalam Islam. Jurnal Syari'ah dan Hukum Islam, $2(2), 111-127$.

Rahmi, A. (2015). Mekanisme Pasar Dalam Islam. Jurnal Ekonomi Bisnis dan Kewirausahaan , 4 (2), 177-192. 